\section{Psykiaterens møte med stornazistene}

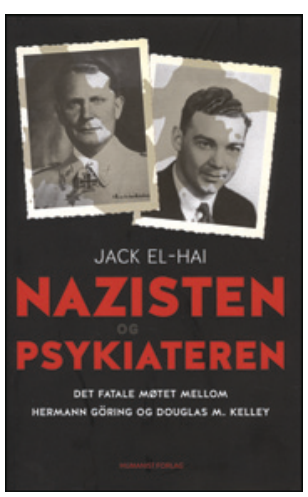

Jack El-Hai

Nazisten og psykiateren

Det fatale møtet mellom Hermann Göring

og Douglas M. Kelley. 357 s, ill. Oslo:

Humanist Forlag, 2014. Pris NOK 369

ISBN 978-82-82820-87-5

I denne boken forteller forfatteren historien om den amerikanske psykiateren Douglas M. Kelleys møte med Hermann Göring og andre naziledere etter siste verdenskrig.

Kelley var født i 1912 og valgte psykiatrien som spesialitet, med doktorgrad og klinisk utdanning. Han ble spesialist på Rorschachmetoden og skrev flere bøker og artikler om «testen». Under krigen ble han sendt til Europa, der han først gjorde en stor innsats $i$ behandlingen av traumatiserte soldater. Etter krigen ble han lege for de nazistiske topplederne og fikk da også i oppgave å vurdere fangenes psyke, og å avgjøre om de var skikket for en fremtidig rettsprosess. Kelley kom således i kontakt med både admiral Karl Dönitz, riksmarskalk Hermann Göring, general Wilhelm Keitel, utenriksminister Joachim von Ribbentrop, rustningsminister Albert Speer og en rekke andre nazikoryfeer.

Kelley fikk et spesielt nært forhold til Hermann Göring, som var 52 år gammel da han ble pågrepet ved krigens slutt. Göring vokste opp i tysk Sørvest-Afrika som sønn av en embetsmann. Under første verdenskrig fikk han nærmest legendestatus i Tyskland på grunn av sin innsats som flyver. Drevet av opportunisme og maktbegjær sluttet han seg tidlig til nazistpartiet. Hitler utpekte ham til leder for de paramilitære brunskjortene i SA (Sturmabteilung). Etter press fra myndighetene på grunn av sin deltakelse i Hitlers kuppforsøk i München i 1923 forlot Göring Tyskland og bodde i Sverige og Italia frem til 1927. Da Hitler ble kansler i 1934, var Göring en av partiets øverste organisatorer. Göring elsket pomp og prakt, staselige uniformer og medaljer. Han tok del i «de lange knivers natt», opprettelsen av Gestapo og de første konsentrasjonsleirene, og forberedte krig i nært samarbeid med Hitler.

Under kuppet i München ble Göring skutt i låret. En påfølgende infeksjon lenket ham til sykehussengen i flere måneder, og han ble avhengig av morfin. Den slanke flyveren fra første verdenskrig ble forvandlet til en fet mann på 140 kilo, og han ble til tider rasende, paranoid, stormannsgal og søvnløs. Under oppholdet i Sverige i 1924 ble han til slutt brutalt avvent på Långbro sinnessjukhus i Stockholm. Etter et par sprekker tok hans rusmisbruk angivelig en pause på flere år, men en tannpine tvang ham tilbake til de narkotiske stoffene, denne gang kodein, med et alarmerende høyt forbruk under krigen.

Kelley fikk som nevnt et spesielt forhold til den intelligente Göring, som gråt da Kelley forlot Nürnberg.
Hvorfor hadde nazistene begått de forferdelige grusomhetene? Var de sinnssyke, kunne en psykisk forstyrrelse forklare deres djevelskap? Dette var vanlige spørsmål som ble stilt etter krigen, også av profesjonelle og forskere. Kelleys langvarige kontakt med fangene gjorde ham overbevisst om at praktisk talt ingen av dem var mentalt forstyrret. Ikke engang de mektigste av dem var monstre eller sjelløse roboter uten følelser.

Göring, Rosenberg, Streicher, Ribbentrop, Jodl, Keitel, Kaltenbrunner, Frank, Frick Seyss-Inquart og Sauckel skulle henges 16. Oktober 1946. Dagen før henrettelsen skulle finne sted, klarte imidlertid Göring å begå selvmord ved å hente ut av kroppen eller toalettet en glassampulle med kaliumcyanid.

Da Kelley kom tilbake til USA senhøstes 1945, sto han foran en hektisk arbeidsdag med undervisning, konsultasjoner, fjernsynsprogrammer, foredrag og evaluering av politifolk, samtidig som han skulle oppfylle sine plikter som ektemann og far, blant annet laget han middag hver eneste kveld. Han elsket å undervise og nøt å være $\mathrm{i}$ begivenhetenes sentrum.

Men ekteskapet var konfliktfylt, og Kelley begynte å drikke og fikk stadig irrasjonelle raseriutbrudd som skremte livet av barna. En dag, etter en voldsom krangel med kona, forsvant han inn på kontoret, kom tilbake og skrek: «Dette finner jeg meg ikke i lenger. Jeg tar dette kaliumcyanidet og er død om et halvt minutt!» Han svelger cyanidet, på samme vis som Göring hadde gjort, foran øynene på en skrekkslagen familie. Året var 1958, Kelley var da 46.

Jack el-Hai har intervjuet blant andre Kelleys eldste sønn, som var i besittelse av farens omfattende papirer fra Nürnberg. Det er blitt en interessant bok med til dels nye detaljer om stornazistenes siste dager. Men i likhet med mange andre amerikanske bøker er denne også noe omstendelig, samtidig som det er ting vi savner. Kelley levde åpenbart i et ulykkelig ekteskap, men hva besto problemene egentlig i? Det får vi ikke vite.

\section{Einar Kringlen}

Professor emeritus, Psykiatrisk institutt, Vindern Universitetet i Oslo 